\title{
Resistivity and georadar mapping of lacustrine and glaciofluvial sediments in the late-glacial to postglacial Store Åmose basin, Denmark
}

\author{
ERIK STEN, HANS THYBO \& NANNA NOE-NYGAARD
}

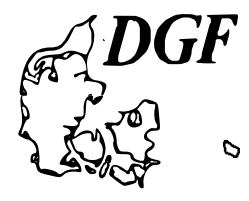

\begin{abstract}
Sten, E., Thybo, H. \& Noe-Nygaard, N.: Resistivity and georadar mapping of lacustrine and glaciofluvial sediments in the late-glacial to postglacial Store Âmose basin, Denmark. Bulletin of the Geological Society of Denmark, Vol. 43, pp. 8798. Copenhagen, 1996-07-14. https://doi.org/10.37570/bgsd-1996-43-10
\end{abstract}

Resistivity profiling, resistivity sounding, georadar profiling and analyses of borings are used in a sedimentological and geomorphological study of shallow subsurface deposits in the proximal (southeastern) part of the Store Åmose lacustrine basin in eastern Denmark. Areas of low, intermediate and high resistivities are located by resistivity profiling. Low-resistivity areas (type I)correspond to a thick unit of water-saturated lake sediments (fine detritus gyttja and silt/clay) which were deposited in a large lake system from the late Weichselian to the late Holocene. In intermediate-resistivity areas (type II), a relatively thick top layer of fresh-water peat and drifted gyttja or dry gyttja occurs. Fine-grained lake sediments, drifted gyttja and peat are equivalent to transparent facies and low penetration (max. c. $2 \mathrm{~m}$ ) in georadar profiles. Resistivity soundings indicate a shallower high-resistive substratum of meltwater sand and gravel in type II areas than in type I areas. The lake and fen sediments fill a highly irregular lake bottom relief, interpreted to have been formed in glaciofluvial channel systems and as dead-ice holes during the final Weichselian deglaciation. Sandy and gravelly domes and ridges, interpreted as proximal glaciofluvial deposits, are exposed at the ground surface in high-resistivity areas (type III). Convex surfaces of glaciofluvial bars and sides of meltwater channels are distinct georadar reflectors. Shallow, glaciofluvial bars were islands in the Holocene lake system and surrounding intermediate-resistivity areas represent shore zones of these islands (possible settlement areas).

Erik Sten*, Hans Thybo and Nanna Noe-Nygaard, Geological Institute, University of Copenhagen, Øster Voldgade 10, DK-1350 Copenhagen K, Denmark, 28th February 1996. * Present address: Hveensvej 1A 3.th, DK-2300 Copenhagen S, Denmark.

\section{Introduction}

Postglacial lake basins in Denmark have previously been mapped by use of resistivity methods (Klitten 1972, Andersen 1976) and a combined use of resistivity methods and georadar has been applied in an earlier investigation of the Store Åmose lake basin in western Sjælland, East-Denmark (Albrechtsen 1991). Here we present new resisivity and georadar data from a scientific investigation of late-glacial to postglacial lacustrine and glaciofluvial sediments in the southeastern part of Store Åmose.

The spatial extent of sedimentary units of different resistivity is mapped by resistivtity profiling. Vertical successions of geophysical layers are identified by resistivity sounding and the range of resistivity and thick- ness of individual geophysical layers is determined by modeling. Vertical sections through the shallow subsurface are provided by georadar profiling. Lithological and geomorphological interpretations of the sedimentary units are based on the combined results of resistivity profiling, resistivity soundings, georadar profiling and shallow borings. A short overview of late Weichselian to late Holocene depositional environments in the Store Åmose basin is presented. 


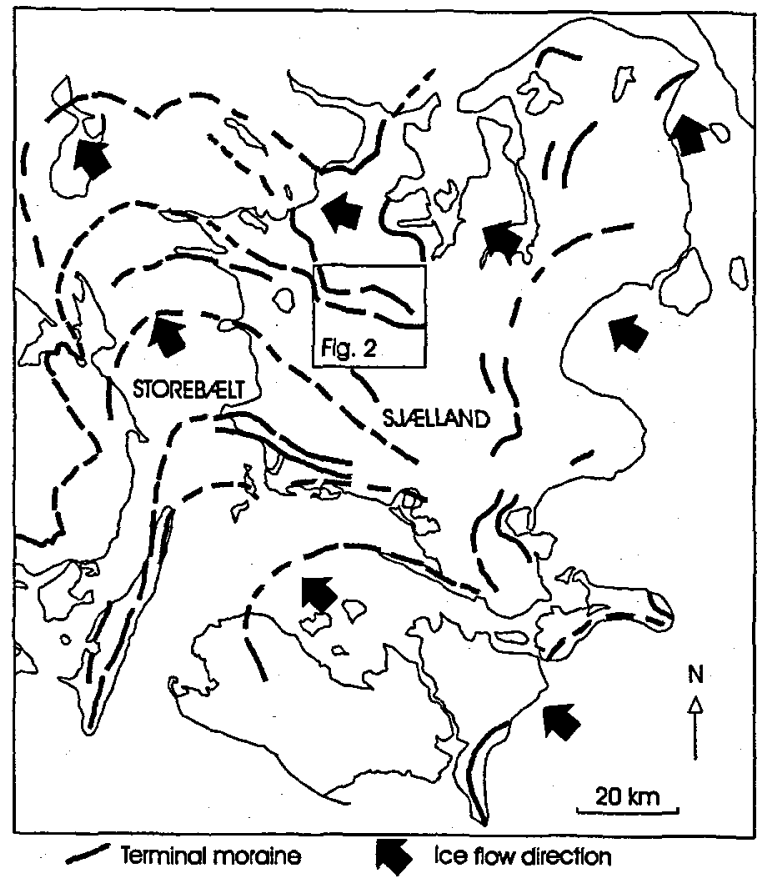

Fig. 1. Location of the Store Åmose valley (Fig. 2) in relation to interpreted recessional terminal moraines connected to the final Weichselian deglaciation. Based on data from Houmark-Nielsen (1981) and Jensen (1993).

\section{General setting and previous investigations}

The Quaternary Store Åmose valley is located above a Paleocene marine sedimentary basin contained within a presumed structurally controlled depression in the top surface of Danien limestone (Andersen 1979). The relief of the pre-Quaternary surface is not mapped in detail. In western Sjælland, Early to Middle Weichselian marine deposits (Ældre Yoldialer) seem to occur in a depression containing Paleocene marine sediments, indicating that subsidence continued during the Quaternary (Andersen 1979).

Deposits of the late-glacial to postglacial Store Åmose lake system cover an area of c. $36 \mathrm{~km}^{2}$ in a c. $13 \mathrm{~km}$ long funnel-shaped glacial valley between terminal moraines that mark recessional positions of two major ice lobes of the final Weichselian ice cap, a southern ice lobe in the Storebælt area and SW-Sjælland and a northern ice lobe in NW-Sjælland (Fig. 1). WNW-ESE oriented terminal moraines occur along the southern margin of the Store Amose valley and a hilly glacial landscape with numerous glacial lake deposits is situated to the north of the valley (Humlum 1983). Two glacial valleys terminate in the southeastern part of the Store Åmose valley (Figs 2 and 3). The straightened stream channels of present-day Sandlyng $\AA$ and $\AA$ mose $\AA$ (Halleby $\AA$ ) merge in the eastern part of the Store Amose valley from where a single stream

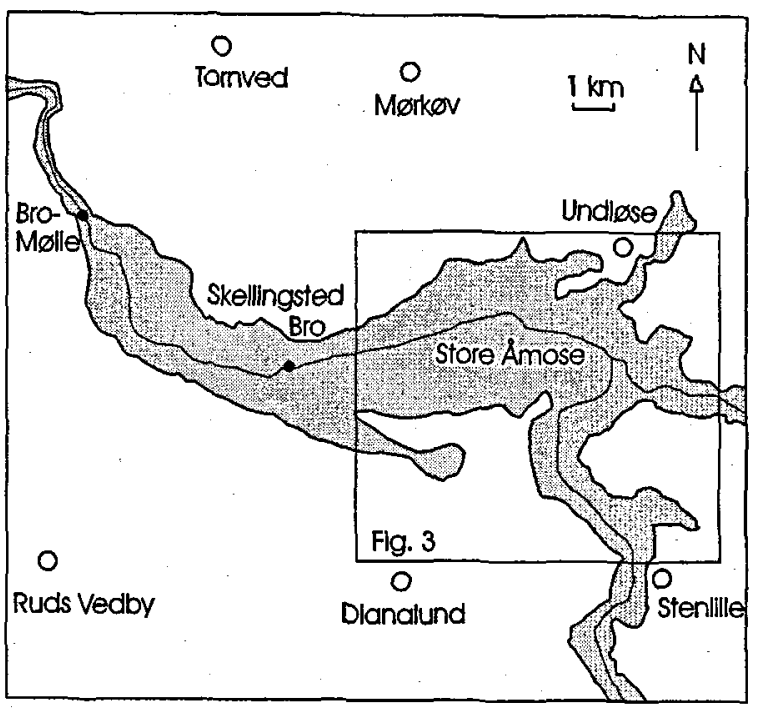

Fig. 2. Geographical map of the Store Amose valley and surrounding areas.

continue westward along the valley axis. It leaves the valley in its narrow northwestern part where a threshold exists at c. $+25 \mathrm{~m}$ at Bromølle (Milthers 1943).

An early mapping of the surface geology made by Rørdam in 1890-96 revealed a widespread layer of fresh-water peat in the Store Åmose bog (DGU 1977a). This peat layer was later intensively excavated for fuel during World War I and II. Later lowering of the ground-water table by drainage and cultivation of the bog surface has caused further compaction and destruction of the former widespread peat cover (Noe-Nygaard 1995).

The Store Åmose lacustrine basin has been the subject of studies of archaeology, palynology, palaeobiology, sedimentology, stable-isotope geochemistry and applied geophysics. We refer to Noe-Nygaard (1995) for a complete list of previous investigations. Archaeological finds from the Late Boreal, Atlantic and Early Subboreal periods mainly occur along lake margins and on islands in the Store Åmose basin (Andersen 1983). The lacustrine basin can be divided into at least four deep sub-basins surrounded by shallower areas (Noe-Nygaard 1995). Iso-ohmm maps from the eastern part of Store Åmose (Fig. 3) outline two sub-basins of low-resistive lake sediments separated by highresistive areas of sand and gravel deposits not covered by lake sediments (Albrechtsen 1991). The iso-ohmm maps indicate that the complex resistivity pattern may continue southeastward. Therefore this southeastern (proximal) part of Store Amose was selected for the present resistivity and georadar survey (Fig. 3). 


\section{Geophysical data acquisition}

Resistivity profiling and sounding

Resistivity methods are used to identify sedimentary units of different electrical conductivity which increases with the content of porewater, clay minerals and salt (Christensen 1987).

By resistivity profiling, using a portable ABEM Terrameter, lateral resistivity variations are mapped on a grid of profiles separated by c. $50 \mathrm{~m}$ (Fig. 4a). The apparent resistivity value is measured every $17 \mathrm{~m}$ with two Schlumberger configurations with fixed potential electrode spacing $(2 \mathrm{~m})$. Because the potential electrodes remain stationary during measurement any local anomalies in ground resistivity near the potential electrodes will have equal influence on both measurements. With the large electrode spacing (10-2-10 m), resistivity is determined for an investigation depth of $1.1-5.5 \mathrm{~m}$, averaging around $2.8 \mathrm{~m}$. With the short electrode spacing (5-2-5 $\mathrm{m}$ ) resistivity is measured for a smaller investigation depth of $0.6-3.0 \mathrm{~m}$, averaging around $1.5 \mathrm{~m}$.

Resistivity soundings in a Schlumberger configuration are used to detect vertical variations in ground resistivity and to determine thicknesses of sedimentary units. Thirteen resistivity soundings were made (Fig. 4b) in zones of extreme resistivity profiling values and in areas of intermediate resistivity. Soundings are primarily oriented parallel to iso-ohmm contour lines. Orthogonal soundings with common midpoint were made at five sounding locations in order to test

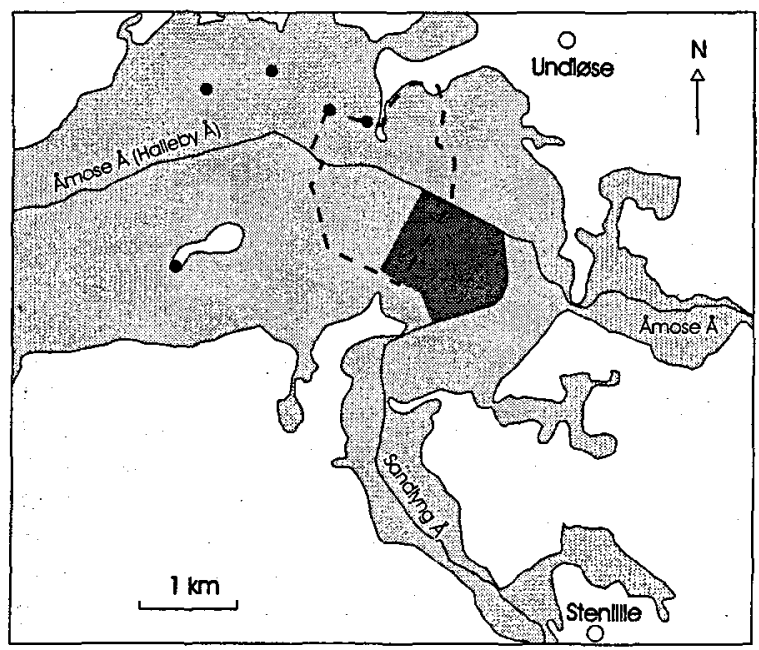

Fig. 3. The eastern part of the Store Amose bog as indicated by the extent of freshwater peat in 1890-96 (after DGU 1977a). Dark grey area= present study area; stippled line $=$ study area of Albrechtsen (1991); filled circles= 10-15 m deep water wells (after DGU 1977b). the fundamental assumption of horizontal, parallel layers. For the interpretation, qualitative inspection of the resistivity sounding curves determine the number of geophysical layers and approximate resistivities for each layer. This is followed by computer based modeling and inversion of the sounding curves for determination of resistivity and thickness intervals for each geophysical layer. For the modeling it is assumed that the resistivity of each layer is isotropic. Shallow borings were made at the midpoint of some resistivity soundings (Fig. 4b) in order to check lithology and thickness of individual layers.

\section{Georadar profiling}

The georadar (ground penetrating radar) method provides vertical sections through the shallow subsurface similar to reflection seismic sections. Pulses of electromagnetic energy are transmitted in the frequencyband of $10-1000 \mathrm{MHz}$ and reflected radiowaves caused by contrasts in dielectric properties in the ground (Davis \& Annan 1989) are detected. Reflection strength is approximately proportional to the difference in dielectric constants at boundaries between sedimentary units of different lithology, grain size or water content (Davis \& Annan 1989). Source and receiver antennas are pulled by a vehicle. The georadar section shows a vertical profile through the shallow subsurface with a vertical scale of two-way travel-time in nanoseconds $\left(10^{-9}\right.$ seconds). Assuming a constant velocity of radiowaves in the ground above a reflector, the twoway travel-time $t$ to the reflector may be converted into depth $\mathrm{d}$ by the formula $\mathrm{d}=1 / 2 \mathrm{vt}$ where the velocity $\mathrm{v}$ is assumed to be $0.055 \mathrm{~m} / \mathrm{ns}$ by calibration with shallow borings in Store Àmose. The presence of electrolytic conductors in the subsurface causes attenuation of the radiowaves and reduces their penetration into the ground (Davis \& Annan 1989). Weakest attenuation and deepest penetration is achieved in high-resistive silica sand and gravel deposits without silt and clay (Jol \& Smith 1992).

In Store Åmose, georadar profiles were recorded along three lines (Fig. 4b) using a SIR-10 radarsystem and antennas with centerfrequencies of $100 \mathrm{MHz}$. Data were recorded digitally and a strong ground surface reflection was removed by a background-removal processing tecnique. Interpreted lithology and thickness of the upper layer was checked in a shallow boring along georadar line 2 (Fig. 4b). 


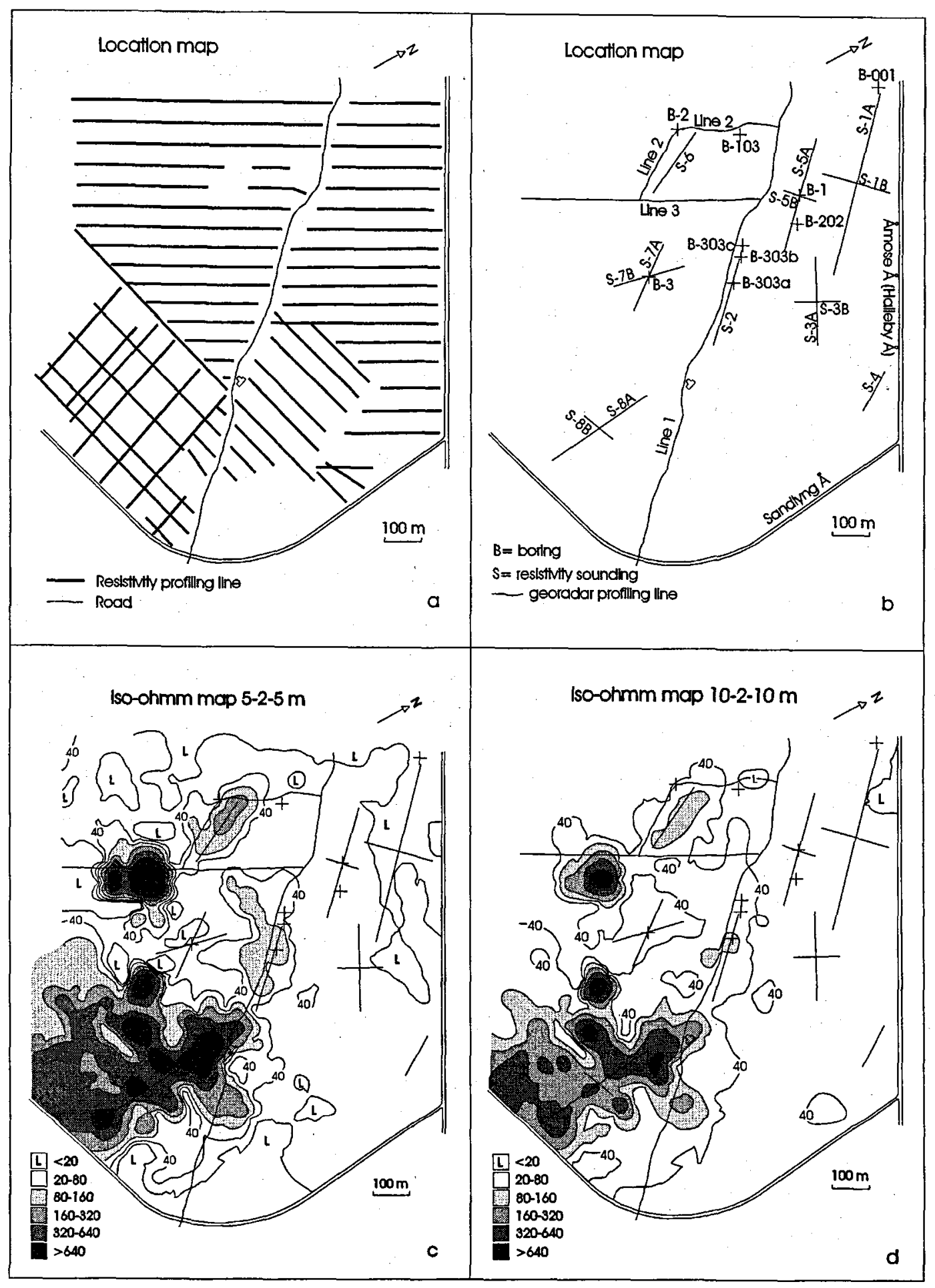

Fig. 4. Location maps of (a) the grid of resistivity profiling lines; (b) borings, resistivity soundings and georadar profiling lines. Iso-ohmm maps based on resistivity measurements with short electrode spacing (c) and large electrode spacing (d). $\mathrm{L}=$ low-resistivity areas (type I); 20-80 ohmm intervals= intermediate-resistivity areas (type II); shades of grey outline high-resistivity areas (type III). 
Table 1. Combined results of inverse modeling of thirteen resistivity sounding curves. $I=$ low-resistivity areas; II $=$ intermediate-resistivity areas; $\mathrm{III}=$ high-resistivity areas.

\begin{tabular}{|c|c|c|c|c|c|c|}
\hline $\begin{array}{l}\text { Geophysical } \\
\text { layer }\end{array}$ & $\begin{array}{l}\text { Interpreted } \\
\text { lithology }\end{array}$ & $\begin{array}{l}\text { Resistivity } \\
\text { interval }\end{array}$ & $\begin{array}{l}\text { Thickness } \\
\text { interval }\end{array}$ & $\begin{array}{l}\text { Depth to } \\
\text { top of layer }\end{array}$ & $\begin{array}{l}\text { Number of } \\
\text { soundings }\end{array}$ & $\begin{array}{l}\text { Occurence } \\
\text { (area type) }\end{array}$ \\
\hline Layer la & $\begin{array}{l}\text { Dry gyttja or } \\
\text { peat and drifted gyttja }\end{array}$ & $28-42 \mathrm{ohmm}$ & $0.4-1.3 \mathrm{~m}$ & $0 \mathrm{~m}$ & 4 & II \\
\hline Layer 1b & $\begin{array}{l}\text { Water-saturated } \\
\text { gyttja and silt/clay }\end{array}$ & $14-24 \mathrm{ohmm}$ & $1.6-5.7 \mathrm{~m}$ & $0-1.3 \mathrm{~m}$ & 8 & I, II \\
\hline Layer $2 \mathrm{a}$ & Dry sand and gravel & $158-698$ ohmm & $2.5-4.7 \mathrm{~m}$ & $0 \mathrm{~m}$ & 4 & III \\
\hline Layer $2 b$ & $\begin{array}{l}\text { Water-saturated } \\
\text { sand and gravel }\end{array}$ & $43-157 \mathrm{ohmm}$ & $38-71 \mathrm{~m}$ & $1.6-6.4 \mathrm{~m}$ & 11 & I; II, III \\
\hline Layer 3 & Paleocene marine clay & $3-15 \mathrm{ohmm}$ & - & $45-75 \mathrm{~m}$ & 7 & I, II \\
\hline
\end{tabular}

\section{Geophysical interpretations}

\section{Resistivity profiling}

Contour lines in the iso-ohmm maps (Figs $4 \mathrm{c}$ and $4 \mathrm{~d}$ ) outline areas of low $(<20 \mathrm{ohmm})$, intermediate $(20-$ $80 \mathrm{ohmm})$ and high $(>80 \mathrm{ohmm})$ resistivity values. The two iso-ohmm maps are different indicating vertical resistivity variations in the shallow subsurface.

\section{Type I: Low-resistivity areas}

Several low-resistivity areas are detected in the study area. A large elongated low-resistivity area occurs in the northern part of Fig. 4c along Amose $\AA$ (Halleby $\AA$ ). Low-resistivity areas occuring along the western rim of Fig. $4 c$ are known to continue to the west of the studied area (Albrechtsen 1991). Minor isolated lowresistivity areas in Figs $4 \mathrm{c}$ and $4 \mathrm{~d}$ are subcircular with diameters ranging from a few tens of meters to about one hundred meter.

Comparison of the two iso-ohmm maps (Figs $4 \mathrm{c}$ and 4d) reveal the presence of a low-resistive layer at shallow depth with a substratum of higher resistivity because of the general increase in measured resistivities from short to large electrode spacing.

\section{Type II: Intermediate-resistivity areas}

Intermediate-resistivity (i.e., 20-80 ohmm) areas cover about half of Fig. $4 \mathrm{c}$ and approximately three quarters of Fig. 4d. The measured resistivity values in general fall within the $20-40 \mathrm{ohmm}$ resistivity range in both iso-ohmm maps. In areas with high resistivity gradients (closely spaced iso-ohmm curves), resistivity values of 40-80 ohmm are measured with both electrode spacings. The zones of $40-80 \mathrm{ohmm}$ are narrower in Fig. $4 c$ than in Fig. $4 d$.

Type II areas are interpreted with a top layer of high resistivity or a thin low-resistivity layer above a shallower high-resistivity substratum.

\section{Type III: High-resistivity areas}

Areas with resistivity values exceeding $80 \mathrm{ohmm}$ cover about a quarter of Fig. 4c and slightly less of Fig. 4d. A large type III area of highly irregular form with a length of several hundred meters occurs in the southern part of both iso-ohmm maps (Figs $4 \mathrm{c}$ and $4 d$ ). Three type III areas of subcircular to elongated form with lengths of a few hundred meters are located in the central and western part of both iso-ohmm maps. There seems to be an overall NNW-SSE orientation of the large and smaller type III areas.

In type III areas, resistivity values of small investigation depth (Fig. 4c) generally exceed values of large investigation depth (Fig. 4d). Thus in these areas a top layer of very high resistivity overlies a substratum of relatively high resistivity. Maximum resistivity profiling values, exceeding $2000 \mathrm{ohmm}$, are measured in the central parts of type III areas.

\section{Resistivity soundings}

Thirteen resistivity sounding curves have been analyzed in order to identify the vertical successions of resistivity. The assumption of horizontal layers for the modeling process is supported by the fact that sounding curves of five pairs of orthogonal soundings with common midpoint are identical. By comparing model resistivities of all thirteen sounding curves, we conclude that five layers $(1 \mathrm{a}, 1 \mathrm{~b}, 2 \mathrm{a}, 2 \mathrm{~b}$ and 3$)$ can describe the studied part of Store Amose (Table 1). All layers, except for layer 3 , contribute to the average resistivity values measured by the resistivity profiling. The sounding curves in general can be classified into three different groups. In the following we discuss resistivities, thicknesses and depths and the expected accuracies. 


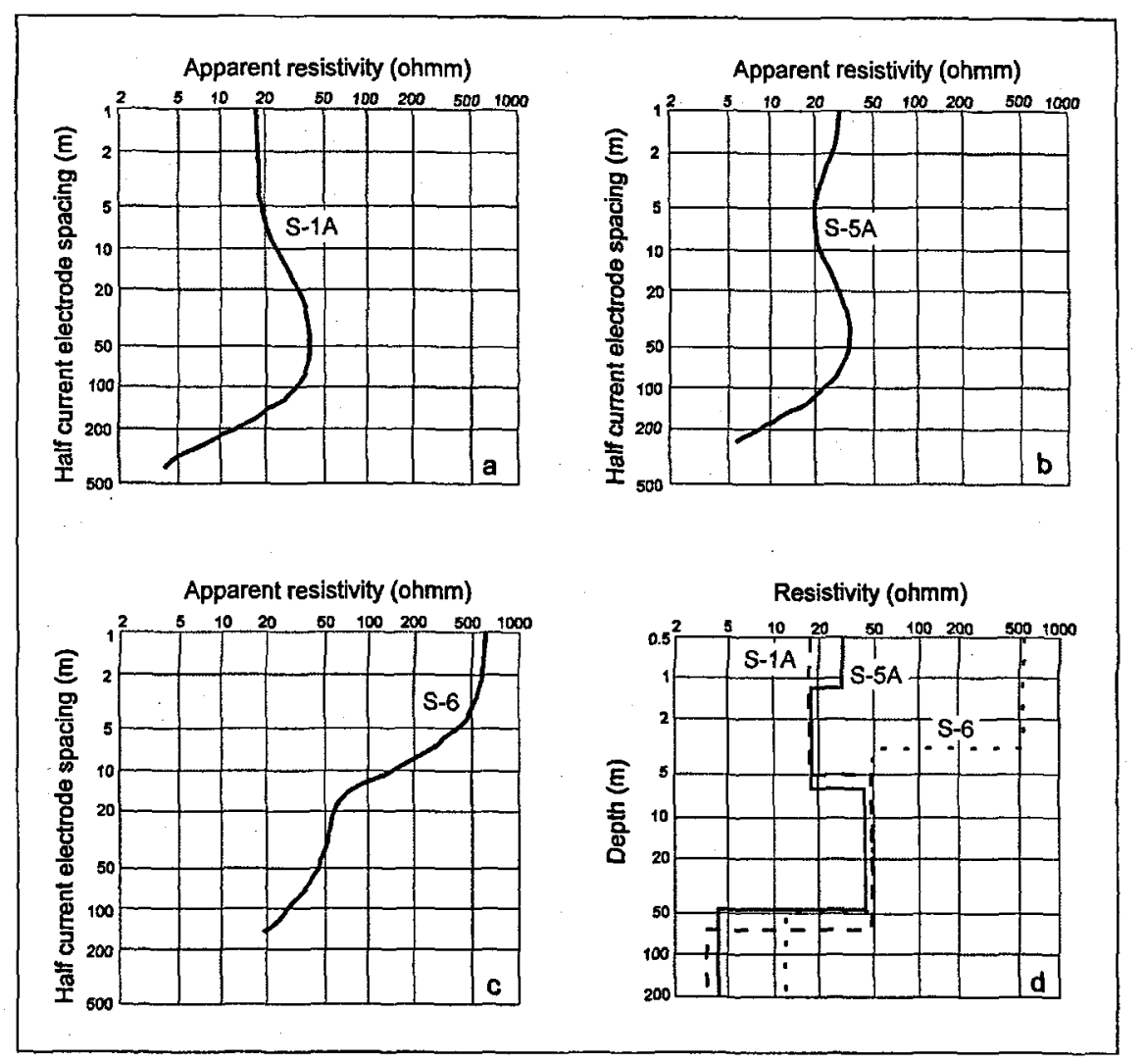

Fig. 5. Resistivity sounding curves from (a) a lowresistivity area (type $I$ ), (b) an intermediate-resistivity area (type II) and (c) a high-resistivity area (type III). (d) Resistivity-depth models of sounding curves in (a), (b) and (c). Locations of resistivity soundings are shown in Fig. 4b.

\section{Type I: Low-resistivity areas}

Fig. 5a shows a resistivity sounding curve (S-1A in Fig. 4b) that is typical for type I areas in Store Amose. The sounding curve is of "maximum-type" which can be explained by a three layer earth in a low-high-low resistivity suite (Fig. 5d). Inverse modeling of the sounding curve provides well-determined values of resistivity, thickness and depth of all layers without other constraints. For the uppermost layer (1b) the resistivity is $17 \mathrm{ohmm}$ and the thickness is $4.5-5.5 \mathrm{~m}$ (Fig. 5d). The resistivity value of the high-resistivity layer (2b) is relatively well-determined ( $44-49 \mathrm{ohmm}$ ) because of its great thickness (53-62 m) although some high-resistivity equivalence is expected (Christensen 1987). The lowermost layer (3) has a very low modeled resistivity of $3-4 \mathrm{ohmm}$ and the modeled depth to this layer is $58-67 \mathrm{~m}$ (Fig. 5d).

\section{Type II: Intermediate-resistivity areas}

The sounding curve in Fig. 5b (S-5A in Fig. 4b) is representative for type II areas in Store Amose. This sounding curve indicates a four layer earth and is simiIar to sounding curves of type I areas (Fig. 5a) except for the presence of a surface layer of intermediate resistivity (Fig. 5d). Modeling results are uncertain because of equivalence between thickness and resistivity for layer two and three. To constrain resistivity and thickness of the second and third layer, knowledge of either resistivity or thickness of the layers is necessary (Christensen 1987). The thickness of the surface layer $(1.15 \mathrm{~m})$ and the second layer $(5.20 \mathrm{~m})$ was measured in a shallow boring (B-1 in Fig. 8) at the midpoint of sounding S-5A. The handcore drill was not able to penetrate into the third (high-resistivity) layer. On this basis the sounding curve was modeled with fixed thickness values of the first and second layer. Modeled resistivities are $30 \mathrm{ohmm}$ for the surface layer (1a), 17 ohmm for the second layer (1b), $43 \mathrm{ohmm}$ for the third layer (2b) and 2-6 ohmm for the fourth layer (3) (Figs $5 \mathrm{~d}$ and 8). Assuming the same resistivity level for the third and the fourth layers as for the second and third layers of sounding S-1A (Fig. 5d), a thickness of 38$43 \mathrm{~m}$ of layer $2 \mathrm{~b}$ and a depth of $45-49 \mathrm{~m}$ to layer 3 was modeled (Fig. 5d). 

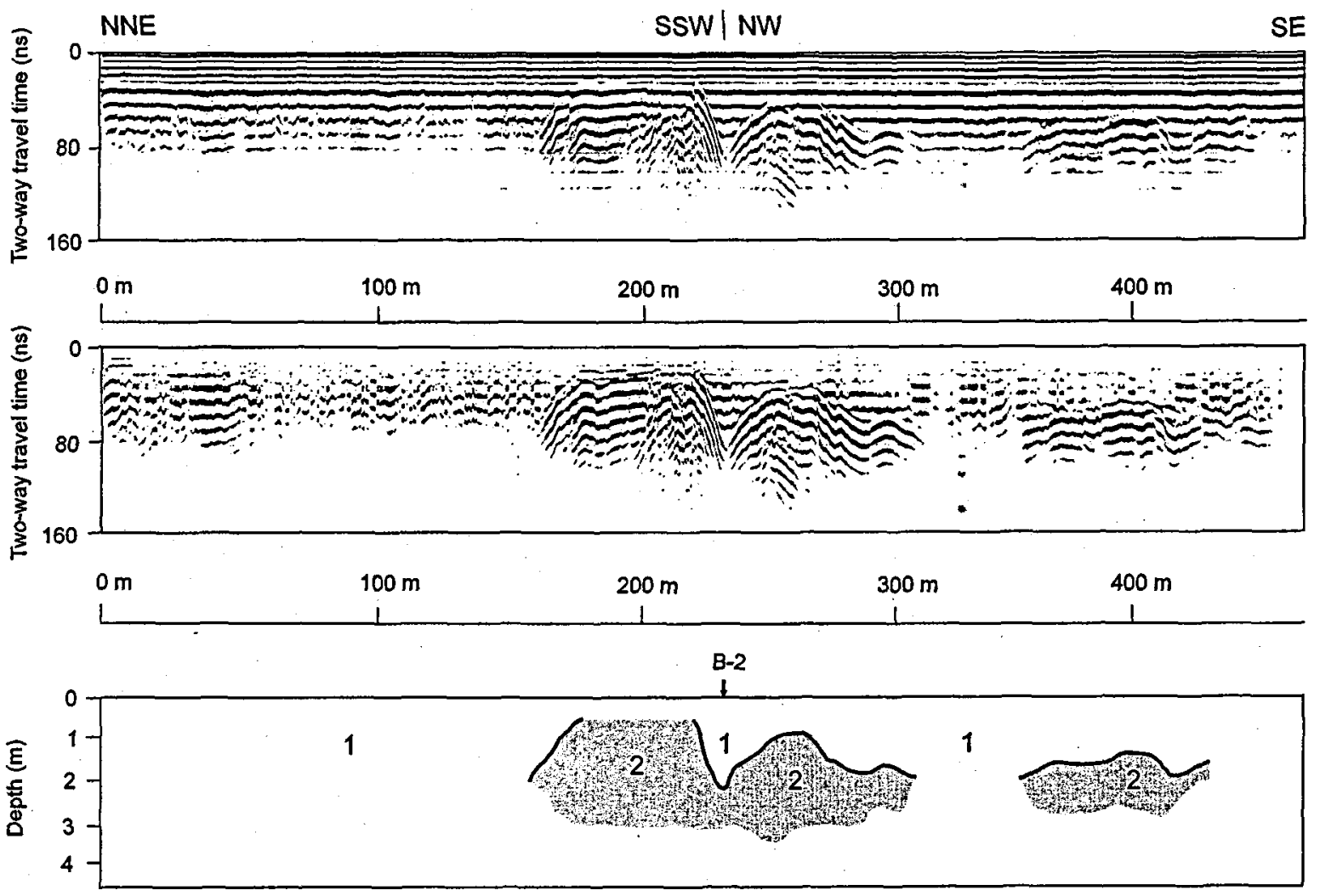

Fig. 6. Georadar line 2 (vertical exaggeration 17 times). Original georadar profile at top, processed georadar profile without ground surface reflection in the middle and interpretation below. $1=$ facies 1 (gyttja); 2 = facies 2 (sand/gravel). Location of the georadar line is shown in Fig. 4b.

Type III: High-resistivity areas

The sounding curve in Fig. 5c (S-6 in Fig. 4b) represents a three layer earth of decreasing resistivity with depth (Fig. 5d) and is representative for type III areas in Store Amose. The resistivity of the uppermost layer (2a) is very high ( $580 \mathrm{ohmm})$ and well-determined and also its thickness of 3.1-3.2 m (Fig. 5d) is well-determined. Resistivity of the second layer (2b) is well-determined $(50 \mathrm{ohmm})$ while its thickness $(34-57 \mathrm{~m})$ is uncertain. For sounding curves of this type the second layer is often suppressed and its thickness is underestimated (Christensen 1987). Assuming the same resistivity levels for the second and third layers as for sounding S-1A (Fig. 5d), the modeled depth to layer 3 is 57$62 \mathrm{~m}$ (Fig. 5d). Resistivity of the third layer is poorly determined by modeling ( $6-26 \mathrm{ohmm})$ but the sounding curve shows that layer 3 is low-resistive.

\section{Georadar profiling}

Two different facies separated by a strong boundary reflector are identified in the georadar profiles (Figs 6 and 7). The upper facies 1 is characterized by a low penetration depth (c. $80 \mathrm{~ns}$ ) and a lack of internal reflectors which suggests a fine-grained homogeneous sediment. The greatest thickness of facies 1 coincides with resistivity areas of less than 40 ohmm for the short electrode spacing (Fig. 4c), suggesting that facies 1 is a sediment of low to intermediate resistivity. A relatively thin cover of facies 1 is present in resistivity areas of $40-80 \mathrm{ohmm}$ at Fig. 4c.

Facies 2 occurs underneath the strong boundary reflector and is characterized by greater penetration depth (up to c. $125 \mathrm{~ns}$ ) in the georadar profiles (Figs 6 and 7). Any possible internal reflectors in facies 2 are overprinted by the boundary reflector. The strong reflection at the boundary between facies 1 and 2 must be caused by a distinct lithological contrast between the two facies. The deeper penetration into facies 2 suggests a coarse-grained sediment. Where facies 1 is absent and facies 2 is present in Figs 6 and 7, resistivity values exceed $80 \mathrm{ohmm}$ for the short electrode spacing (Fig. 4c), indicating that facies 2 is a high-resistive sediment. 

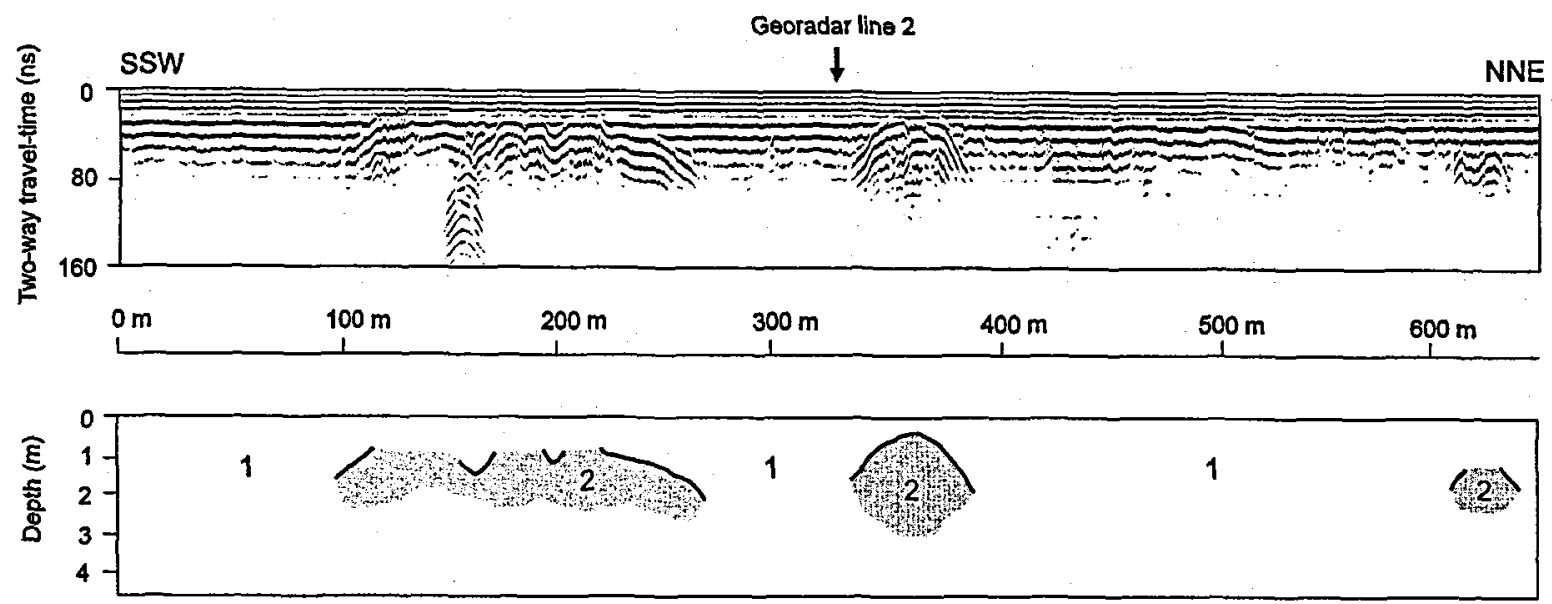

Fig. 7. Georadar line 3 (vertical exaggeration 19 times). Original georadar profile at top with interpretation below. $1=$ facies 1 (gyttja); 2 = facies 2 (sand/gravel). Location of the georadar line is shown in Fig. $4 b$.

\section{Geological interpretations}

Resistivity data and interpretations show that five main layers (1a, 1b, 2a, 2b and 3) may describe the uppermost sedimentary succession in Store Åmose (Table 1).

\section{Layer 1a. Dry gyttja or peat and drifted gyttja}

A surface layer of dry gyttja or strongly humified peat and drifted gyttja is commonly present in borings in type I and II areas in Figs $4 c$ and $4 d$. We interpret this organic horizon as equivalent to the intermediate-resistivity layer 1a modeled in soundings $\mathrm{S}-3 \mathrm{~A}, 3 \mathrm{~B}, 5 \mathrm{~A}$, 5B, 7A and 7B (Figs $4 \mathrm{~b}$ and 8 ). In type II areas, layer $1 \mathrm{a}$ is $0.4-1.2 \mathrm{~m}$ thick (borings $\mathrm{B}-1,2,3,103$ and $303 \mathrm{~b}$ in Figs $4 b$ and 8). In type I areas, layer $1 \mathrm{a}$ is $0-0.5 \mathrm{~m}$ thick as $0.5 \mathrm{~m}$ of dry gyttja and drifted gyttja was measured in boring B-001 (Fig. 8) and no intermediate-resistivity surface layer was modeled in soundings S-1A (Fig. 5a) and S-1B. These core and resistivity data show, that layer 1a thins laterally from type II areas, with a maximum thickness of $1.2 \mathrm{~m}$ in boring B-1 (Fig. 8 ), into type I areas where up-to $0.5 \mathrm{~m}$ occurs.

Thickness values of layer $1 \mathrm{a}$, obtained by modeling of resistivity soundings, are not well-determined because of a relatively thick capillary zone in the finegrained gyttja or a gradual lithological change from coarse drifted gyttja to fine gyttja of the underlying sedimentary unit (layer $1 \mathrm{~b}$ ).

\section{Layer 1b. Water-saturated gyttja and silt/clay}

Water-saturated, fine-grained lake sediments were penetrated in all borings but one in type I and II areas and were modeled as a low-resistivity layer (1b) in all soundings in type I and II areas. In shallow parts of the lacustrine basin, layer $1 \mathrm{~b}$ is a homogeneous, fine detritus gyttja or a laminated, calcareous gyttja (borings B-2, 3, 202 and 303b in Figs 4b and 8). In deeper parts of the basin, layer $1 \mathrm{~b}$ consists of an upper gyttja unit and a lower unit of rhytmically laminated silt and clay with isolated pebbles (borings B-1,001 and 103 in Figs $4 \mathrm{~b}$ and 8). An increase in sand content occurs in the lowermost part of layer $1 \mathrm{~b}$ in the deepest boring (B001 in Fig. 8). Maximum thicknesses of $2.9 \mathrm{~m}$ for the upper gyttja unit and $5.6 \mathrm{~m}$ for the lower silt/clay unit were measured in boring B-001 (Fig. 8) and the total thickness of $8.5 \mathrm{~m}$ of water-saturated, fine-grained lake sediments in this boring is assumed to be near to the maximum thickness in the studied area. A $1-15 \mathrm{~cm}$ thick, sheet-like, erosive-based, pebbly sand layer is present in the transition zone between the lower and upper unit of fine-grained lake sediments throughout the eastern part of Store Åmose (Noe-Nygaard 1995). This sand layer is however much too thin to be modeled as an individual layer in resistivity soundings.

Based on core and resistivity data, we conclude that layer $1 \mathrm{~b}$ is $0-5.2 \mathrm{~m}$ thick in type II areas (borings B-1, $2,3,103,202,303 \mathrm{~b}, 303 \mathrm{c}$ and soundings $\mathrm{S}-3 \mathrm{~A}, 3 \mathrm{~B}$, $5 \mathrm{~A}, 5 \mathrm{~B}, 7 \mathrm{~A}$ and $7 \mathrm{~B}$ in Figs $4 \mathrm{~b}$ and 8 ) and $5-8.5 \mathrm{~m}$ thick in type I areas (boring B-001 and soundings $S$ $1 \mathrm{~A}$ and $1 \mathrm{~B}$ in Figs $4 \mathrm{~b}$ and 8 ). Thus layer $1 \mathrm{~b}$ thickens laterally from type II areas into type I areas with a maximum thickness of $8.5 \mathrm{~m}$ measured in boring $\mathrm{B}$ 001 (Fig. 8). The greatest thickness of layer $1 \mathrm{~b}$ is expected in type I areas at the iso-ohmm map of large electrode spacing (Fig. 4d). The thickness of layer $1 \mathrm{~b}$ is well-determined by modeling of resistivity soundings in type I areas but more uncertain in type II areas.

Based on a comparison of core and resistivity data from type I and II areas, we conclude that the larger resistivity profiling values of type II areas are due to a thicker surface layer (1a), a thinner unit of finegrained 
Fig. 8. A comparison between resistivity-depth models and lithological logs of borings. The key boring B-001 mentioned in the text is also shown. Interpreted resistivity layers are labelled $1 \mathrm{a}, 1 \mathrm{~b}$ and $2 \mathrm{~b}$. Lithological data from boring B-001 are simplified from Albrechtsen (1991). Locations of borings and resistivity soundings are shown in Fig. $4 b$.

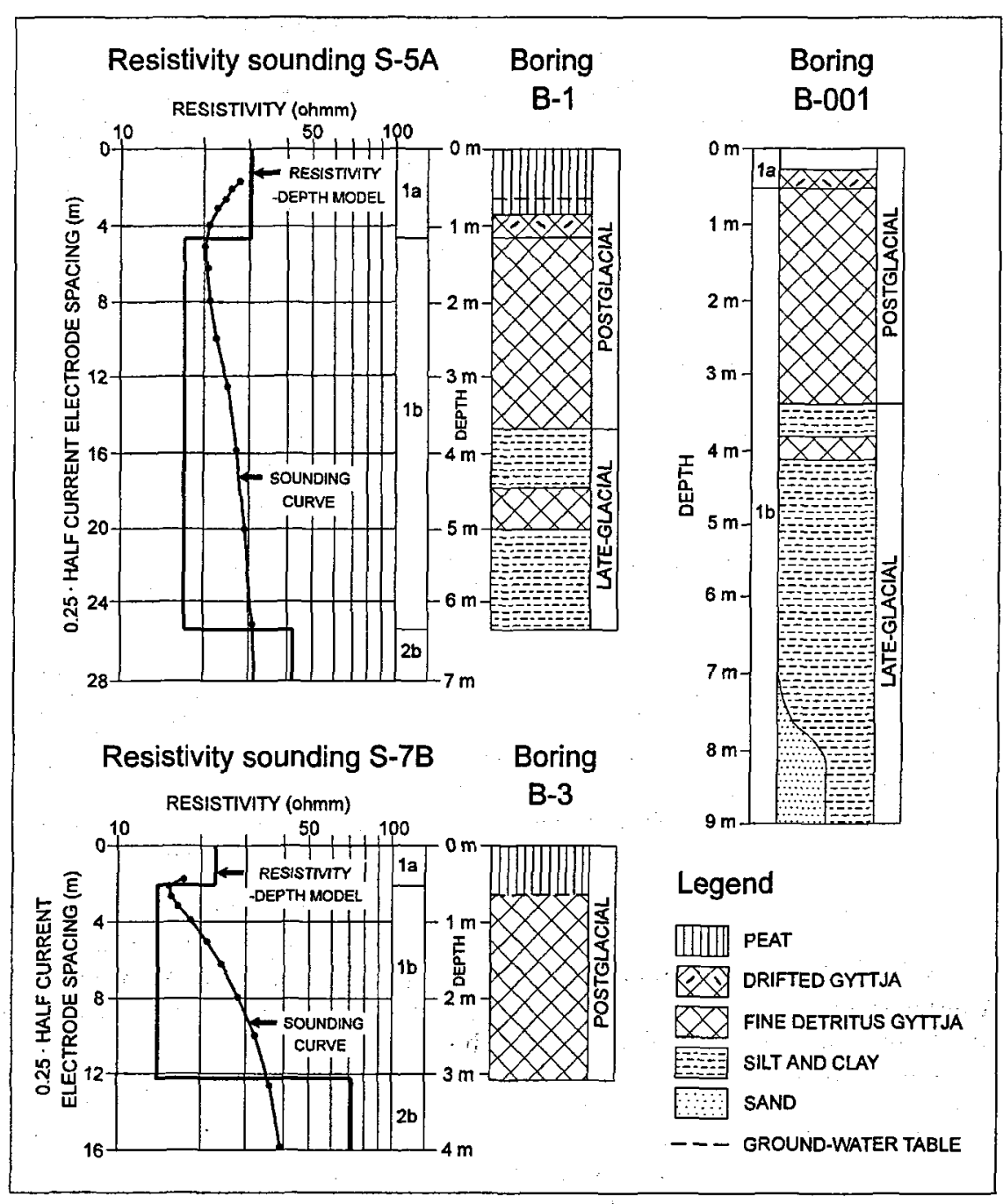

lake sediments (layer 1b) and a shallower substratum (layer $2 b$ ) than in type I areas.

\section{Layer 2a. Dry sand and gravel}

A coarse-grained, poorly sorted sand and gravel deposit with pebbles and cobbles occurs just below the ground surface in boring B-303a (Fig. 4b) in a type III area. This observation and the high resistivity values (158-698 ohmm) of the surface layer 2a (Table 1) indicate, that type III areas consist of dry sand and gravel. A maximum clast size of c. $20 \mathrm{~cm}$ among cobbles on the ground surface in type III areas suggests deposition under high-energy conditions. The occurence of coarse-grained sand and gravel deposits in front of interpreted terminal moraines (Fig. 1) suggests a proglacial high-energy meltwater environment.

Type III areas coincide with up-to a few meters topographical highs above the surrounding flat terraines of relatively lower resistivity. Variations in resistivity profiling values within individual type III areas are most likely caused by variations in thickness of the dry sand and gravel layer since maximum resistivities are measured in central parts of these highs where the unsaturated zone is expected to be thickest. Individual high-resistivity areas form domes or elongated ridges while close-lying high-resistivity areas coalesce to form large, irregularly shaped sand and gravel bodies (Figs $4 \mathrm{c}$ and $4 \mathrm{~d})$. Well-determined thicknesses $(2.5-4.7 \mathrm{~m})$ of layer 2a (Table 1) were obtained from resistivity soundings $\mathrm{S}-2,6,8 \mathrm{~A}$ and $8 \mathrm{~B}$ (Fig. $4 \mathrm{~b}$ ).

\section{Layer $2 b$. Water-saturated sand and gravel}

Layer $2 b$ forms a widespread high-resistive substratum in Store Åmose as it is modeled in all resistivity soundings. The handcore drill used could not penetrate into this layer which must be a coarse-grained clastic 
sediment. The modeled resistivity range of the layer is 43-157 ohmm (Table 1), suggesting that its lithology is water-saturated sand and gravel or clayey/sandy till (limestone can be excluded). Only meltwater sand and gravel is found in the uppermost $10-15 \mathrm{~m}$ of water wells in the eastern part of Store Åmose (Fig. 3). Layer $2 \mathrm{~b}$ most likely represents more than one geological layer, considering its great thickness of 46-71 m (Table 1), which is of the same order of magnitude as the thickness of the whole Quaternary sequence in a deep well at Skellingsted Bro in the western part of Store Åmose (Fig. 2). Here c. $55 \mathrm{~m}$ of Quaternary sediments may be divided into three main lithological units (from top to bottom): c. $22.5 \mathrm{~m}$ of meltwater sand/gravel, c. $20 \mathrm{~m}$ of clayey/sandy till and c. $12.5 \mathrm{~m}$ of meltwater gravel (DGU 1977b). A similar tripartite build-up of the Quaternary sequence may occur in the eastern part of Store Åmose, but here no wells penetrate deeper than 10-15 m (DGU 1977b).

The thickness of layer $2 \mathrm{~b}$ can be determined by modeling of resistivity soundings where it is covered by only one geophysical layer such as water-saturated, fine-grained lake sediments (layer 1b) or dry sand and gravel (layer 2a) but not where a relatively thick cover of dry gyttja or peat and drifted gyttja (layer 1a) is present. Approximate thickness values of layer $2 b$ have been obtained by use of known thicknesses of layer 1a and $1 \mathrm{~b}$.

\section{Layer 3. Paleocene marine clay}

This lowermost layer is identified by resistivity sounding underneath the high-resistive substratum (layer 2b) in type I areas (S-1A and 1B in Fig. 4b) and type II areas (S-3A, 3B, 5A, 5B, 7A and 7B in Fig. 4b). The presence of layer 3 is not verified by resistivity sounding in type III areas (S-2, 6, 8A and $8 \mathrm{~b}$ in Fig. 4b) but layer 3 is likely to occur throughout the area. The very low resistivity range of 3-15 ohmm (Table 1) suggests that layer 3 consists of clay or contains saltwater. In a deep well at Skellingsted Bro (Fig. 2), marine clay of Paleocene age occurs beneath Quaternary layers from a depth of c. $55 \mathrm{~m}$ (DGU 1977b). This depth matches the depth to layer $3(45-75 \mathrm{~m})$ in the southeastern part of Store Åmose as obtained from resistivity soundings (Table 1). Layer 3 is thus interpreted as Paleocene marine clay. Depth to the pre-Quaternary surface (top surface of layer 3) can be determined by modeling of resistivity sounding curves in type $I$ areas whereas it is uncertain in type II and III areas.

\section{Georadar profiling}

Facies 1 fills a c. $30 \mathrm{~m}$ wide and c. $2 \mathrm{~m}$ deep $\mathrm{V}$-form in the georadar profile (Fig. 6) around the shallow boring B-2 (Fig. 4b) where facies 1 consists of fine detritus gyttja, which is water-saturated from a depth of $c$.
$0.5 \mathrm{~m}$. The small grain size causes low penetration into the gyttja and the homogeneous lithology explains the lack of internal reflectors. In boring B-103 (Fig. 4b), located at c. $100 \mathrm{~m}$ in Fig. 6, $0.7 \mathrm{~m}$ of drifted gyttja (layer 1a) overlies $1.9 \mathrm{~m}$ of gyttja, sand and clay (layer 1b). These core data show that facies 1 is equivalent to both layer $1 \mathrm{a}$ and $1 \mathrm{~b}$.

The V-form seen in Fig. 6 is interpreted as a shallow gyttja-filled channel. The sides of a larger, c. $140 \mathrm{~m}$ wide, gyttja-filled channel are seen between 220 and $360 \mathrm{~m}$ at georadar line 3 (Fig. 7). The bottom of this channel is undetermined because the depth of the channel exceeds maximum penetration of radiowaves in gyttja (c. $2 \mathrm{~m}$ ). The georadar profiles (Figs 6 and 7) clearly portray the convex surface of facies 2 which is interpreted as sand and gravel deposits of ridge or dome morphology.

\section{Depositional environments}

During deglaciation of the retreating Young Baltic Bælthav ice stream, at 15,000-14,000 B.P. (HoumarkNielsen 1987), large meltwater drainage systems were formed and high-energy outwash sediments were deposited in the Store Amose valley, especially at the outlet of the glacial (Sandlyng $\AA$ ) valley that drained meltwater from major stagnant and dead ice masses of central Sjælland (Milthers 1943). The glaciofluvial sediments in Store Åmose may have been laid down partly in tunnel valleys and partly in front of the stagnant melting southern ice wall of the retreating Young Baltic Bælthav ice (Noe-Nygaard 1995). The surface morphology of proximal glaciofluvial deposits is preserved and partly exposed today in the southeastern part of Store Åmose as bars, elongated ridges and large irregularly formed sand/gravel bodies (high-resistivity areas in Figs $4 c$ and $4 d$ ) ranging in size from less than one hundred meter to a few hundred meters length. Meltwater flowed in braided channel systems between the sandy and gravelly bars. Shallow channel forms are seen at georadar profiles, while deep channel forms are not easily recognized because of the limited penetration of radiowaves (c. $2 \mathrm{~m}$ ) in the gyttja and silt/ clay that fill these channels.

During the final Weichselian deglaciation dead ice masses blocked the narrow outlet in the northwestern part of the Store Åmose valley and a large ice-dammed lake formed which existed from approximately 13,000 10,000 B.P. (Noe-Nygaard 1995). A prolonged Gilbert-type delta, prograding north- and westwards into the lake basin, was located by georadar profiling to the west of the present-day Sandlyng $\AA$ stream outlet (Albrechtsen 1991). Its steep eastern side suggests, that it may have been bounded by ice-barriers during delta formation (Albrechtsen 1991). Delta progradation took place before the onset of the Postglacial period (NoeNygaard 1995). Fine-grained clastic sediments were 
supplied to the glacial lake by erosion of till, glaciofluvial and glaciolacustrine deposits in the sparsely vegetated, hilly terraines surrounding the valley. Silt and clay were deposited in a low-energy environment at the lake bottom in deeper parts of the basin (in the former glaciofluvial channel systems and in depressions created by melting dead-ice blocks) levelling out the irregular bottom topography of the glacial lake. Silt/clay laminae represent true varves in a period around 13,000 B.P., but deposition of silt and clay as distal turbidites in a background deposition of massive clay also occured (Noe-Nygaard 1995). Icetransported pebbles were occasionally dropped at the bottom of the glacial lake. A fall in water level of several meters, probably caused by tapping of the icedammed lake at the Younger Dryas-Preboreal transition around 10,000 B.P., is indicated by a thin, pebbly sand layer that separates the fine-grained, clastic lake sediments form an upper unit of fine gyttja (NoeNygaard 1995).

A large, open lake system existed for a period of $c$. 5,000 years from approximately 10,000-5,000 B.P. (Noe-Nygaard 1995). Mainly drifted gyttja was deposited along lake shores and fine detritus gyttja was deposited in low-energy environments in deeper parts of the basin. The upwards change in lithology from clastic to organic lake sediments is interpreted to result from an increase in organic production in the lake system, possibly combined with a reduced supply of clastic material to the lake system. This marked change in sediment type and lake quality was most likely caused by the Postglacial climatic amelioration (Noe-Nygaard 1995) already initiated by the late-glacial Bølling and Aller $\varnothing$ d oscillations. Lake margins and islands were seasonnally inhabited by man as shown by archaeological finds from the Late Boreal to the Early Subboreal (Andersen 1983). Noe-Nygaard (1995) correlated lake level fluctuations in the Store Åmose basin with changes in relative sea- and ground-water level during the Atlantic and Early Subboreal. Around 5,000 B.P., the open water lake system turned into a fen system and accumulation of peat increased. In the Late Subboreal Phragmites and Alnus peat covered large areas of the Store Åmose basin and after Subboreal times thick layers of Sphagnum peat probably covered most of the basin (Noe-Nygaard 1995). Later intensive peat-digging and lowering of the ground-water table has removed and partly destructed the former widespread peat cover and exposed the fine-grained lake sediments and coarse-grained glaciofluvial deposits.

Interpreted glaciofluvial sand and gravel highs, approximately outlined by the $80 \mathrm{ohmm}$ contour line in Fig. 4c, probably were islands in the Holocene lake system as we know that other sand/gravel highs in the basin have been inhabited by people from the Late Maglemose-, Kongemose- and Late Erteb $\varnothing l l e-c u l t u r e s$ (Andersen 1983). Surrounding type II areas of 20-80 ohmm in Figs $4 \mathrm{c}$ and $4 \mathrm{~d}$ are interpreted as shore zones of Holocene islands. Resistivity soundings and borings in type II areas show a maximum total thickness of 6.4 $\mathrm{m}$ of peat and lake sediments (boring B-1 in Figs 4b and 8). These intermediate-resistivity areas may be of potential interest for future archaeological excavations in Store Åmose.

\section{Conclusions}

Contrasts in electrical conductivity and dielectrical properties between fine-grained lacustrine and coarsegrained meltwater deposits make the combined use of resistivity and georadar profiling an effective geological tool for mapping of these sediment types in Store Åmose and in other shallow-water lake and fen deposits. Individual resistivity layers are identified by resistivity sounding. Lithologies and modeled thicknesses of layers must be checked in borings.

Resistivity soundings and core data show a two-partite build-up of lake and fen deposits. Peat and drifted gyttja or dry gyttja form a resistivity layer (1a) of 28$42 \mathrm{ohmm}$ with a maximum thickness of $1.2 \mathrm{~m}$ (boring B-1 in Fig. 8). Water-saturated, fine detritus gyttja and silt/clay form a low-resistive layer (1b) of 14-24 ohmm with a maximum thickness of $8.5 \mathrm{~m}$ (boring B-001 in Fig. 8). Layer 1a thins laterally and layer $1 \mathrm{~b}$ thickens laterally from intermediate-resistivity areas (type II) into low-resistivity areas (type I). Lake and fen deposits reach a maximum total thickness of $9 \mathrm{~m}$ in boring B-001 (Fig. 8). The thickness of water-saturated, finegrained gyttja and silt/clay may be determined by resistivity sounding unless covered by a relatively thick unit of dry gyttja or peat and drifted gyttja. Fine-grained lake sediments, filling former meltwater channel systems and dead ice holes, are transparent in georadar profiles however only up to a thickness of c. $2 \mathrm{~m}$. Channel sides are distinct georadar reflectors.

The morphology of sand and gravel highs, interpreted as proximal glaciofluvial bars, is outlined in the horizontal plane by resistivity profiling and in vertical sections by georadar profiling. The coarse-grained sediments are exposed at the ground surface in highresistivity areas (type III). They are covered by up-to $6.4 \mathrm{~m}$ of lake sediments and peat (boring B-1 in Fig. 8 ) in surrounding type II areas of intermediate resistivity. Type II areas are interpreted as shore zones of islands in the Holocene lake system (possible settlement areas).

\section{Acknowledgements}

Field-work was carried out in August to December 1994. Georadar profiling and processing of georadar data was done by Frank Andreasen, Dansk Geoservice. We wish to thank Henning Hansen at Bodal Gods for 
permission to work in the area. Christian Abildtrup and Arne Mogensen are thanked for field-assistence, Olav Brogaard and Alexander Lassen for computerassistence. The reviewers Kurt Klitten and Holger Lykke Andersen gave constructive comments and advice on the manuscript.

\section{Dansk sammendrag}

Geoel-profilering, geoel-sondering, georadar-profilering og boringsdata er anvendt $i$ en sedimentologisk og geomorfologisk unders $\varnothing$ gelse af overfladenære aflejringer i den proximale (sydøstlige) del af Store Åmose på Vestsjælland. Områder med lave, intermediære og høje modstandsværdier (resistivitetsværdier) er lokaliseret ved geoel-profilering. Lavmodstandsområder (type I) svarer til en tyk lagpakke af vandmættede søsedimenter (fin detritus-gytje og silt/ler), der er aflejret i en stor ferskvandss $\varnothing$ fra Senglacialtid til sen Holocæn, hvor søen gradvist groede til. I områder med intermediære modstandsværdier (type II) findes et relativt tykt overfladelag af ferskvandstørv og drift-gytje eller umættet gytje. Finkornede søsedimenter, driftgytje og tørv udg $\varnothing r$ en gennemsigtig georadar-facies med ringe nedtrængningsdybde (maksimalt ca. $2,5 \mathrm{~m}$ ). Geoel-sonderinger indicerer, at et høj-resistivt underlag af smeltevandssand og -grus ligger højere i type II områder end i type I områder. S $\varnothing$ - og moseaflejringerne udfylder et meget uregelmæssigt bundrelief, der tolkes dannet i glaciofluviale kanalsystemer og som dødishuller under afsmeltningen af det sidste Weichsel-isdække. Højmodstandsområder (type III) udgøres af sand/grus domer og rygge, der tolkes som proximale glaciofluviale aflejringer. Konvekse overflader af glaciofluviale barrer og sider af smeltevandskanaler udgør reflektorer på radargrammer. Højtliggende glaciofluviale barrer har udgjort øer i det holocæne søbassin, og intermediære modstandsområder omkring højmodstandsområder repræsenterer bredderne af disse øer (mulige bopladsområder).

\section{References}

Albrechtsen, T. 1991: En geofysisk-sedimentologisk unders $\varnothing$ gelse af det sen- og postglaciale lakustrine Åmose bassin, Vestsjælland. 208 pp. M. Sc. Thesis. Geological Institute, University of Copenhagen.

Andersen, H. L. 1976: Geoelectric investigations. In Villumsen, A. and Andersen, H. L.: Late- and Post-glacial sediments in the Randers fjord area. Danmarks geologiske Unders $\emptyset$ gelse, II. Række 107, 93-110.

Andersen, H. L. 1979: Nogle undergrundstektoniske elementer i det danske Kvartær. Dansk geologisk Forening, Årskrift for 1978, 1-6.

Andersen, K. 1983: Stenalderbebyggelsen i Den Vestsjællandske Åmose. 210 pp. Fredningsstyrelsen, Copenhagen.
Christensen, N. B. 1987: Den geoelektriske resistivitetsmetode. In: Geofysik \& råstofkortlægning, 25-73. Råstofkontorets kortlægningsserie nr. 5, Skov- og Naturstyrelsen, Copenhagen.

Davis, J. L. \& Annan, A. P. 1989: Ground-penetrating radar for high-resolution mapping of soil and rock stratigraphy. Geophysical prospecting 37-5, 531-551.

DGU 1977a: Foreløbigt geologisk jordartskort (1:25.000) 1413 II N $\varnothing$ Dianalund. Danmarks geologiske Undersøgelse, Copenhagen.

DGU 1977b: Geologisk basisdatakort (1:50.000) 1413 II Sorø. Danmarks geologiske Unders $ø$ gelse, Copenhagen.

Houmark-Nielsen, M. 1981: Glacialstratigrafi i Danmark øst for Hovedopholdslinien. Dansk geologisk Forening, Årsskrift for 1980, 61-76.

Houmark-Nielsen, M. 1987: Pleistocene stratigraphy and glacial history of the central part of Denmark. Bulletin of the Geological Society of Denmark 36, 189 pp.

Humlum, O. 1983: Geologi, Vestsjællands landskabsformer, 23 pp. Fredningsplanlagning. Vestsjællands Amtskommune, Sorø.

Jensen, J. B. 1993: Late Weichselian deglaciation pattern in the Southwestern Baltic: Evidence from glacial deposits off the island of Møn, Denmark. Bulletin of the Geological Society of Denmark 40, 314-331.

Jol, H. M. \& Smith, D. G. 1992: Geometry and structure of deltas in large lakes: a ground penetrating radar overview. In Hanninen, P. and Autio, S. (eds.) Fourth International Conference on Ground Penetrating Radar, June 8-13, Rovanieme, Finland. Geological Survey of Finland, Special Paper 16, 159-168.

Klitten, K. 1972: Geoelektrisk Kortlægning af Postglaciale Bassiner. Afhandlinger fra Instituttet for Teknisk Geologi No. 1,74 pp.

Milthers, V. 1943: Nordvestsjallands geologi. Danmarks geologiske Undersøgelse, V. Række 6, 185 pp.

Noe-Nygaard, N. 1995: Ecological, sedimentary, and geochemical evolution of the late-glacial to postglacial Åmose lacustrine basin, Denmark. Fossils and Strata 37, 436 pp. 